\title{
VARIOUS MODIFIED POLYESTERAMIDE VARNISHES AS ANTIMICROBIAL GROWTH CONTROL.
}

\author{
M.MOSTAFA., A.M.NASER., F.ABDEL-HAI AND, H. ABD EL-WAHAB \\ Department Of Chemistry, Faculty Of Science (Boys), Al-Aazhr University, Cairo, \\ Egypt.
}

\begin{abstract}
New modified polyesteramide compositions were prepared and evaluated as vehicles for surface coating The resin was prepared by partial replacement of hydroxyl ethyl fatty acid amide (HETSA) by N,N-Bis(2-hydroxyethyl) -p-toluenesulfonamide .This modification, as expected, imp- roved the film performance and durability and lead to substantial antimicrobial growth control.
\end{abstract}

Keywords: Polyesteramide , Surface coating, Biological activity , antimicrobial varnishes growth control, Toluene sulfonamide..

\section{Introduction}

Polymeric systems based on polyesteramides (PEA) are high performance material, which combine the useful properties of polyester and polyamide resins, and finds many applications most importantly as protective surface coatings [1,2]. Diethanolamine derivatives of fatty acids were used in the preparation of polyesteramide and alkyd/ polyesteramide resins [3]. Most alkylolamides are derived from ethanolamine and fatty acids These derivatives are used as the ingredient source of dihydric alcohol for poly condensation [4, 5], Polyesteramide resins containing pentachlorophenol residue in their structure were prepared and evaluated as antimicrobial growth control [6]. Another polyesteramide resins were prepared containing a stoichiometric amount of 8-hydroxquinoline as preservative against microbiolgical attack [7].The other modified polyesteramide resins were prepared in which stoichiometric amount of hydroxyethyl fatty acid amides are replaced by nicotinic and isonicotinic acids derivatives of diethanolamine and triethanolamine. Such resin compositions exhibited antimicrobial growth control [8]. New modified polyesteramide resins were screened for their anti-bacterial activity against E coli, Peseudomonas sp., and staphylococcus sp, and their antibacterial activity was evaluated in the nutrient agar media [9]. In this investigation the chemical incorporation of the biocide in the resins molecules is the main idea which 
4

can be achieved by partial replacement of polyols used in the manufacture of polyesteramide resins by N,N-Bis(2-hydroxyethyl) -p-toluenesulfonamide (modifier). Such modification introduce the biologically active nuclei in the structure of the resin and consequently would expect to affect their biological activity.

\section{Experimental}

All solvents and chemical used through the whole investigation were at least of chemically pure grade, except where mentioned.

\section{Methods of Preparations.}

Preparation of N,N-Bis(2-hydroxyethyl) -p-toluenesulfonamide (HETSA):<smiles>Cc1ccc(S(=O)(=O)N(CCO)CCO)cc1</smiles>

HETSA (I)

A mixture of (one mole) p-toluene sulfonyl chloride and (one mole) of diethanolamine was stirred for three hours in presence of triethylamine as base and diethyl ether as a solvent. The precipitate formed was washed with distilled water and recrystalized from ethanol to give $N, N$-Bis(2-hydroxyethyl) -p-toluene sulfonamide [HETSA] ,I, , (m.p.99 - $101^{\circ} \mathrm{C}$.).<smiles>Cc1ccc(S(=O)(=O)Cl)cc1</smiles>

Tosyl Chloride
DEA<smiles>Cc1ccc(S(=O)(=O)N(CCO)CCO)cc1C=[Te]</smiles>

HETSA 


\section{Preparation of various modified Polyesteramide Resins;}

The preparation of various modified polyesteramide resins were carried out in two general steps:

\section{A. Preparation of $N, N$-bis(2-hydroxyethyl)linseed oil fatty acids amide (HELA):}

A mixture of freshly distilled diethanolamine, DEA (10.5gm, 0.1 mole) and linseed oil fatty acid (28.0 gm, 0.1 mole) was placed in $250 \mathrm{ml}$ round-bottomed flask fitted with Dean and Stark apparatus. The mixture was allowed to reflux until approximately the theoretical amount of water (1.8ml, 0.1 mole) was collected, indicating the complete formation of $N, N$-bis(2-hydroxyethyl)-linseed oil fatty acids amide (HELA).

\section{B. Preparation of Modified Polyesteramide Resins:}

Formulations containing $N, N$-bis(2-hydroxyethyl)linseed oil fatty acids amide (HELA) and or N,N-Bis(2-hydroxyethyl) -p-toluenesulfonamide (modifier)" as the ingredient source of the polyol used, and phthalic anhydride (PA) as the polybasic ingredient were prepared by solvent technique. The reaction was followed by observing the amount of water liberated versus time.

Table (1 ) : Resin characteristic constant of variouse modified polyesteramide resins.

\begin{tabular}{|c|c|c|c|c|c|c|}
\hline $\mathbf{E x}-\mathbf{O H}$ & $\mathbf{e}_{\mathbf{o}}$ & $\mathbf{e}_{\mathbf{A}}$ & $\mathbf{e}_{\mathbf{B}}$ & $\mathbf{R}$ & $\mathbf{K}$ & $\begin{array}{c}\mathbf{H}_{\mathbf{2}} \mathbf{O} \mathbf{~ m l} \\
\text { off }\end{array}$ \\
\hline $\mathbf{0 \%}$ & 0.519 & 0.259 & 0.260 & 1.00 & 1.0 & 2.3 \\
\hline $\mathbf{1 0} \%$ & 0.573 & 0.273 & 0.300 & 1.10 & 1.0 & 2.5 \\
\hline $\mathbf{2 0} \%$ & 0.650 & 0,298 & 0.352 & 1.20 & 1.0 & 2.7 \\
\hline $\mathbf{3 0} \%$ & 0.779 & 0.339 & 0.440 & 1.30 & 1.0 & 3.1 \\
\hline
\end{tabular}

Ex: excees $\mathrm{OH}, \mathrm{e}_{\mathrm{o}}$ :Total Equivalents Present at the start of reaction, $\mathrm{e}_{\mathrm{A}}$ : Number of acid equivalents,

$\mathrm{e}_{\mathrm{B}}$ : Number of Hydroxyl Equivalent, R : Ratio of total-OH groups to total-COOH groups $\left(\mathrm{e}_{\mathrm{B}} / \mathrm{e}_{\mathrm{A}}\right)$, and $\mathrm{k}$ : alkyd constant

The resins were prepared by using linseed oil fatty acids via solvent process, using Dean and stark apparatus, covering a wide range of oil lengths and hydroxyl content $(0,10,20$, and $30 \%$ Excess-OH). within each formulation, the total number of 
6

acid and hydroxyl equivelant were kept constant, and the various hydroxyl equivelant $\left(\mathbf{e}_{\mathbf{B}}\right)$ of each type of Excess-OH resin are listed in Table (2)

Table (2)list of hydroxyl equivelant of various modifications.

\begin{tabular}{|c|c|c|}
\hline Number & HELA & Modifier \\
\hline *A $^{\text {A }}$ & $\mathbf{1 . 0 0}$ & $\mathbf{0 0 . 0}$ \\
B & $\mathbf{0 . 9 0}$ & $\mathbf{0 . 1 0}$ \\
C & $\mathbf{0 . 8 0}$ & $\mathbf{0 . 2 0}$ \\
D & $\mathbf{0 . 7 0}$ & $\mathbf{0 , 3 0}$ \\
\hline
\end{tabular}

*Unmodified formulations (A) was included for comparison

\section{Methods of evaluation:}

Methods of testing and evaluation were performed according to the American standard test methods and including, acid value [10], solid content [11], preparation of test panels [12], viscosity [13], color [14], The pencil hardness [15], film thickness [16], adhesion [17], Gloss [18], flexibility [19], chemical resistance [20], [21], [22], [23].

\section{Microbiology Assay}

The preparation of test specimens; procedure and evaluation of the results were conducted according to standard methods $[24,25]$.

\section{Results and Discussion}

Recently new modified polyesteramide resins were described through the partial replacement of $N, N$-bis(2-hydroxyethyl)linseed oil fatty acids amide (HELA) by N,N-Bis(2-hydroxyethyl) -p-toluenesulfonamide (modifier), such modification showed better film performances and leads to the formation of biological active polyester-amide resins. The modifier N,N-Bis(2-hydroxyethyl) -ptoluenesulfonamide was prepared through the reaction of tosyl chloride with diethanolamine in presence of triethylamine as base. The structure of the modifier was elucidated on the basis of the IR spectrum and HNMR spectrum. 
(1) I.R spectrum (Fig.1), showed a broad band of v-OH alc.at about $3224 \mathrm{~cm}^{-1}$ broad and v-SO at $1161 \mathrm{~cm}^{-1}$; v-C-H aliphatic at $2969 \mathrm{~cm}^{-1}$ and at about $796 \mathrm{~cm}^{-1}$ due to disubstituted benzene ring.

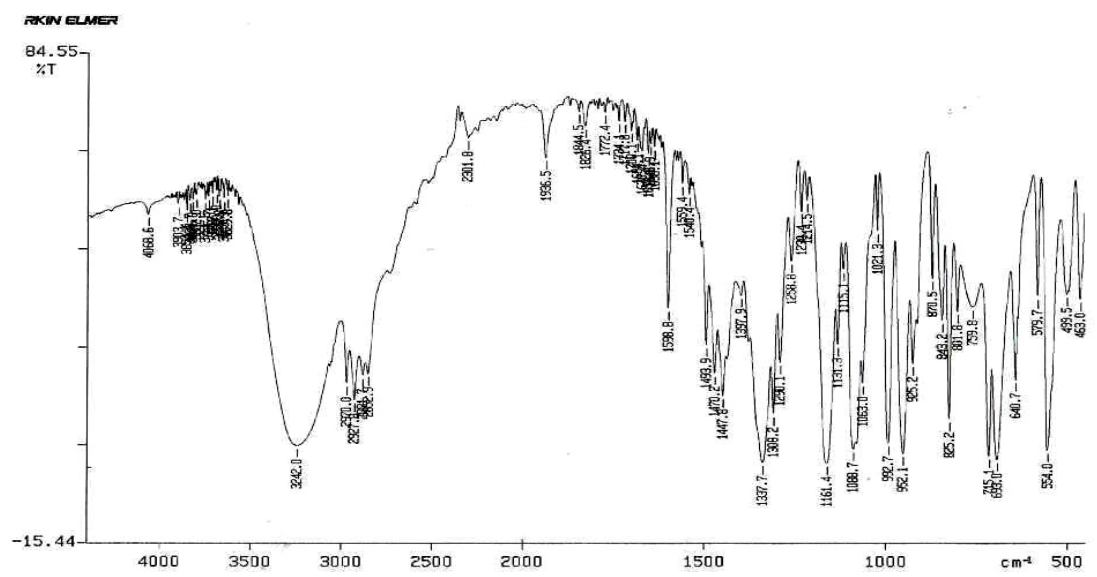

12/02/02 19:28

X:: 1 scan, 4. . Ocm-1
Dr. Hmada (White)

Fig ( 1) I.R Spectra Of. N-N ,bis(2-hydroxyethyl p-toluenesulfonamide(HETSA)

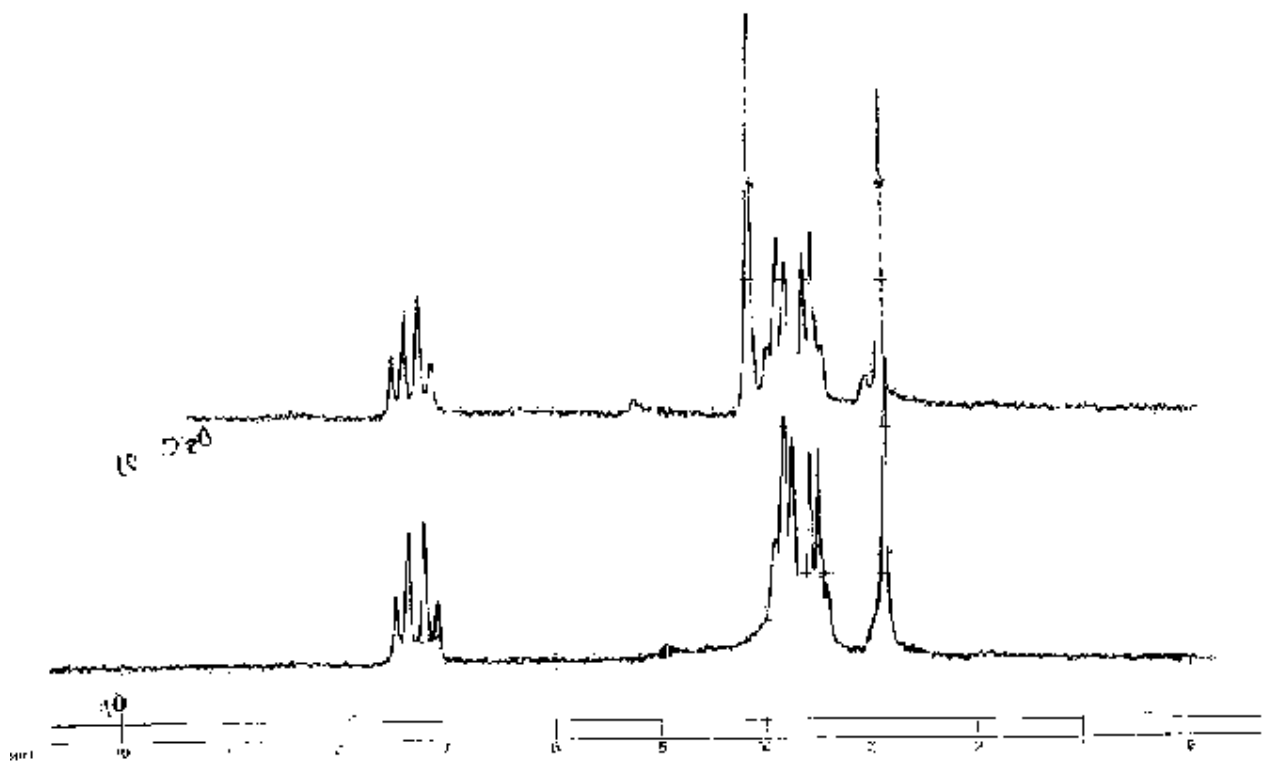


Fig(2) ${ }^{1} \mathrm{H}$ - NMR spectra of bis (2-hydroxyethyl p-toluene sulfonamide(HETSA)

3) ${ }^{1} \mathrm{HNMR}$ spectrum (Fig. 2) was measured in DMSO- $d_{6}$ and showed signals at $\delta$ $=2.7 \mathrm{ppm}\left(\mathrm{t}, 4 \mathrm{H}, 2 \mathrm{CH}_{2}-\mathrm{N}\right.$ ), $4.2\left(\mathrm{t}, 4 \mathrm{H}, 2 \mathrm{CH}_{2}-\mathrm{OH}\right.$ ), 5.0 (hump, $2 \mathrm{H}, 2 \mathrm{OH}$ ), and 7.4$8.2 \mathrm{ppm}(\mathrm{m}, 3 \mathrm{H}, \mathrm{Ar}-\mathrm{H})$.

During the course of the preparation, the amount of water collected in the trap was observed against time of the reaction and the data obtained are graphically represented in fig (3)

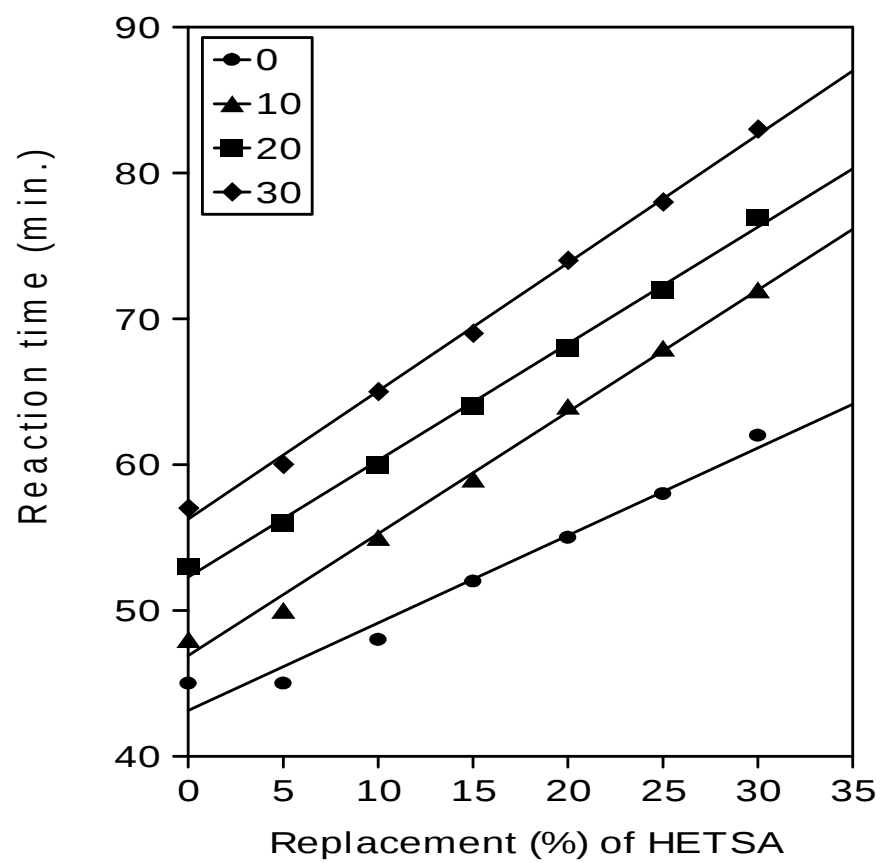

Fig (3) Effect of HETSA on the course of esterification of HETSA-modified polyesteramide resins.

Figure (3) indicates that the reaction time for various resin formulations prepared is proportionally increased by increasing the precentage of modifier.

\section{Evaluation studies:}


Following the preparation of various modified polyesteramide resins, the solid content was adjusted to be $50 \%$ solids, and drier combinations are added then filtration is carried out if necessary . 
0

\section{Varnish characteristics:}

The characteristics of various varnishes prepared were determined and the data are shown in Table (3)

Table (3): Effect of N,N-Bis(2-hydroxyethyl)-p-toluenesulfonamide upon varnish characteristics.

\begin{tabular}{|c|c|c|c|c|c|c|c|c|c|}
\hline $\begin{array}{c}\text { Resin } \\
\text { No. }\end{array}$ & $\begin{array}{c}\text { Excess- } \\
\text { OH } \\
(\%) \\
\end{array}$ & $\begin{array}{c}\text { Replacement } \\
\text { of HETSA } \\
\% \\
\end{array}$ & $\begin{array}{l}\text { Viscosity } \\
\text { (Gardnar) }\end{array}$ & $\begin{array}{c}\text { Color } \\
\text { (Gardnar) }\end{array}$ & $\begin{array}{c}\text { Air } \\
\text { drying } \\
\text { time(h) }\end{array}$ & $\begin{array}{c}\text { Stoving } \\
\text { At } \\
110(1 \mathrm{hr}) \\
\end{array}$ & $\begin{array}{l}\text { Stoving } \\
\text { at110( } 2 \mathrm{hr}\end{array}$ & $\begin{array}{c}\text { Stoving } \\
\text { at } \\
120(1 \mathrm{hr}) \\
\end{array}$ & $\begin{array}{c}\text { Stoving } \\
\text { at120(2hr) }\end{array}$ \\
\hline Ia & \multirow{4}{*}{0} & 0 & $\mathrm{D}$ & $>18$ & 6 & $\mathrm{~T}$ & VST & VST & HD \\
\hline b & & 10 & $\mathrm{H}$ & $>18$ & 4 & ST & VST & HD & \\
\hline c & & 20 & $\mathrm{~K}$ & $>18$ & 3 & VST & VST & HD & \\
\hline $\mathrm{d}$ & & 30 & $\mathrm{O}$ & $>18$ & 2 & HD & & & \\
\hline II a & \multirow{4}{*}{10} & 0 & $\mathrm{~F}$ & $>18$ & 6 & $\mathrm{~T}$ & ST & VST & HD \\
\hline b & & 10 & $\mathrm{~J}$ & $>18$ & 4 & $\mathrm{ST}$ & VST & HD & \\
\hline c & & 20 & $\mathrm{~N}$ & $>18$ & 3 & VST & HD & & \\
\hline d & & 30 & $\mathrm{Q}$ & $>18$ & 2 & HD & & & \\
\hline $\begin{array}{r}\text { III } \\
\text { a }\end{array}$ & \multirow{4}{*}{20} & 0 & $\mathrm{H}$ & $>18$ & 5 & $\mathrm{~T}$ & VST & HD & \\
\hline b & & 10 & $\mathrm{~L}$ & $>18$ & 3 & VST & VST & HD & \\
\hline C & & 20 & $\mathrm{O}$ & $>18$ & 2 & HD & & & \\
\hline d & & 30 & $\mathrm{R}$ & $>18$ & 1.30 & HD & & & \\
\hline IV a & \multirow{4}{*}{30} & 0 & $\mathrm{~K}$ & $>18$ & 5 & $\mathrm{~T}$ & VST & HD & \\
\hline b & & 10 & $\mathrm{O}$ & $>18$ & 3 & VST & HD & & \\
\hline c & & 20 & S & $>18$ & 2 & HD & & & \\
\hline $\mathrm{d}$ & & 30 & $\mathrm{U}$ & $>18$ & 1.30 & HD & & & \\
\hline
\end{tabular}

$\mathrm{T}$ : Tackiness, ST:Slightly tackiness, VST:very slightly tackiness, HD: hard dry

\section{Film performance .}

From the data recorded in table (3), the following conclusions were drawn

1. The color of the prepared modified resins was dark brown (>18in Gardner scale) due to the presence of nitrogenous base.

2. Viscosity of varnishes increases through the addition of the modifier.

3. Air drying and staving time are decreased by increasing the amount of the modifier. 
The dry film characteristics of the various modified resin films were carried out according to standard methods and well- known techniques and the results are tabulated in Tables (4). 
The main conclusion drawn from Table (4) indicate the following generalizations:

1. The modified films show outstanding performance compared with unmodified films.

2. Stoved films exhibit about the same effect for water, acid and solvent resistances compared with air-dried films.

3. Increasing the percentage of modifier leads to a substantial improvement in the film resistances towards water and acid.

4. The solvent resistance of all examined films are excellent and it is not able to show the effect of the modifier

5. The effect of various modifications on the alkali resistance is clearly shown. Increasing the percentage of modification leads to better improvement in the alkali resistances of the air-dried and stoved films. Also, increasing the excess hydroxyl content of the resin greatly improves the alkali resistances of the film.

6. All films passed successfully the flexibility and adhesion tests.

7. The scratch hardness and the gloss of dried films are improved by increasing the amount of modifier.

Microbiological activity of the modified resins was carried out on liquid varnish and dried films and the data are recorded in Tables (5).

Table (5): Antimicrobial Activity of Various modified Polyesteramide Resins

\begin{tabular}{|c|c|c|c|c|c|c|c|c|c|c|c|c|}
\hline \multirow[t]{2}{*}{$\begin{array}{l}\text { Resin } \\
\text { No. }\end{array}$} & \multicolumn{2}{|c|}{$\begin{array}{c}\text { Bacillus } \\
\text { Subtils } \\
\text { ATCC } 7972\end{array}$} & \multicolumn{2}{|c|}{$\begin{array}{c}\text { Staphylococcus } \\
\text { Aureus } \\
\text { NCTC } 7447\end{array}$} & \multicolumn{2}{|c|}{$\begin{array}{c}\text { Ascherichi Coli } \\
\text { NCTC } 10416\end{array}$} & \multicolumn{2}{|c|}{$\begin{array}{c}\text { Pseudomonas } \\
\text { aeruginosa } \underline{\text { ATCC }} \\
10145\end{array}$} & \multicolumn{2}{|c|}{$\begin{array}{c}\text { Candida } \\
\text { Albicans } \\
\text { IMRU3669 }\end{array}$} & \multicolumn{2}{|c|}{$\begin{array}{l}\text { Aspergillus } \\
\text { Niger } \\
\text { ATCC } 6275\end{array}$} \\
\hline & & DF & $\mathrm{V}$ & DF & $\mathrm{V}$ & DF & $\mathrm{V}$ & DF & $\mathrm{V}$ & DF & $\mathrm{V}$ & $\mathrm{DF}$ \\
\hline Ia & 4 & 4 & 4 & 4 & 4 & 4 & 4 & 4 & 4 & 4 & 4 & 4 \\
\hline $\mathrm{b}$ & 4 & 4 & 3 & 4 & 4 & 4 & 4 & 4 & 4 & 4 & 4 & 4 \\
\hline C & 4 & 4 & 2 & 4 & 4 & 4 & 4 & 4 & 4 & 4 & 4 & 4 \\
\hline d & 3 & 3 & 1 & 3 & 3 & 3 & 3 & 3 & 3 & 4 & 4 & 4 \\
\hline IIa & 4 & 4 & 4 & 4 & 4 & 4 & 4 & 4 & 4 & 4 & 4 & 4 \\
\hline $\mathrm{b}$ & 4 & 4 & 2 & 4 & 4 & 4 & 4 & 4 & 4 & 4 & 4 & 4 \\
\hline C & 3 & 4 & 1 & 3 & 4 & 4 & 4 & 4 & 4 & 4 & 4 & 4 \\
\hline d & 3 & 3 & 0 & 3 & 3 & 3 & 3 & 3 & 3 & 3 & 4 & 4 \\
\hline IIIa & 4 & 4 & 4 & 4 & 4 & 4 & 4 & 4 & 4 & 4 & 4 & 4 \\
\hline $\mathrm{b}$ & 2 & 2 & 2 & 2 & 2 & 2 & 3 & 3 & 3 & 3 & 4 & 4 \\
\hline C & 0 & 0 & 0 & 0 & 0 & 0 & 2 & 2 & 3 & 3 & 4 & 4 \\
\hline d & 0 & 0 & 0 & 0 & 0 & 0 & 2 & 2 & 2 & 2 & 4 & 4 \\
\hline IVa & 4 & 4 & 4 & 4 & 4 & 4 & 4 & 4 & 4 & 4 & 4 & 4 \\
\hline b & 0 & 0 & 2 & 2 & 2 & 2 & 2 & 2 & 3 & 3 & 4 & 4 \\
\hline C & 0 & 0 & 0 & 0 & 2 & 2 & 2 & 2 & 3 & 3 & 4 & 4 \\
\hline $\mathrm{d}$ & 0 & 0 & 0 & 0 & 0 & 0 & 2 & 2 & 2 & 2 & 4 & 4 \\
\hline
\end{tabular}

Ia, IIa, IIIa and IVa mens unmidified samples .

V means Varnish in Wet State, and DF means dry film.

0 mens high performance antimicrobial activity

4 means inactive sample against the microorganism. 
4

The results in Tables (5) show that's the various modified polyesteramide resins in different substitutions showed about the same effect in liquid solution as in solid film .The modification increase the antimicrobial activity against the target microorganisms. on the other hand increasing the Excess - $\mathrm{OH} \%$, leads to increasing of the antimicrobial activity. It is noteworthy to mention that, the unmodified polyesteramide resins (formulations "a"), are completely inactive against the microorganisms under investigation.

\section{Reference}

1. L. E.GAST, W. J. SCHNEIDER, G. E. MC-MAINS, AND,C. COWAN, J.Am. Oil. Chem.Soc, 46 (1969) 360.

2. R .N. MUKHERJEA, K. PALS, S.K.SINYAL, J. Appl. Polym. Sci, 28 (1983).

3. M. MOUSTAFA, Pigment Resin Tech, 21 (12) (1992) 4.

4. A. M.RAMADAN, A .Z.GOMMA, Euro. Coat, J. 6 (1992) 349.

5. M. MOUSTAFA, I. A. SABBAH, A. M. NASER, F. ABDDEL-HAI, Pigment\& Resin Tech, 16 (12) (1989) 4

6. N. M. TAHA, M. MOUSTAFA, N. ABDEL-KHALIK, A. M.NASER, Pigment\&Resin Tech, 18 (10) (1989) 4

7. F. ABD EL-HAI, AND H. M. MAHDY., Acta Microbiologica. Et, Immunologica, 44, (2), (1997) 119.

8. M.. MOUSTAFA, F. ABD EL-HAI, SABBAH,.I.A. AND E. M. MOHAMED, , Al-Azhar Journal of Pharmaceutical Science, 15, (1995) 35.

9. A. SHAHZADA, M. D. MAHFUZUL HAQUE, S.M.ASHRAF, S. AHMED, European polymer Journal, 40 (2004) 2097.

10. ASTM Method: D1639-90 (Reapproved 1996).

11. ASTM Method: D1644-88 (Reapproved 1993).

12. ASTM Method: D3891-96

13. ASTM Method: D 1545-89 (Reapprovrd 1993).

14. ASTM Method: D 1544-80 (Reapprovrd 1989).

15. ASTM Method, D 3363-92a

16. ASTM Method, D 1005-95

17. ASTM Method: D 3359-95a

18. ASTM Method: D 523-89.( Reapproved 1994). 
19. ASTM Method, D 522-93a

20. ASTM Method, D 870-92

21. ASTM Method, D 1647-89(reapproved 1996).

22. ASTM Method, D 3260-8(reapproved 1996).

23. ASTM Method: D 2792-69 (Reapproved 1993).

24. ASTM method, D 5589-97,(Reapproved 2002),06. 01 (2004).

25. ASTM method, D 5590-94, (Reapproved 2000) 06.01(2004). 